\section{Transatlantic warning bells sound on rheumatic fever}

Last year saw a resurgence of acute rheumatic fever in the United States of America. Between January 1985 and June 1986 in Salt Lake City, Utah, 74 confirmed cases were seen in one centre compared with six a year for the preceding 10 years. ${ }^{1}$ In Akron, Ohio, 14 children were admitted to the Children's Medical Center in 1986 compared with 25 in all the preceding 10 years. ${ }^{2}$ Again in Ohio, at the Columbus Children's Hospital, in 28 months from 1984 to 198640 patients were seen with acute rheumatic fever compared with 34 in the previous decade. ${ }^{3}$ Occasional epidemics are acceptable, but these and other reports show a multifocal return of rheumatic fever in a country where the disease was thought to be disappearing. ${ }^{45}$

To understand the epidemiological factors associated with the resurgence a basic knowledge of the cell structure of the streptococcus is necessary. From the outside there are five layers: the capsule, the M protein, the group carbohydrate, the mucopeptide, and the protoplast membrane. Streptococci belonging to group $A$ are subtyped by their $M$ protein, and there are over 80 serological types. Many laboratories in the United States of America have noted extremely mucoid strains emerging. In the outbreaks of acute rheumatic fever, too few streptococci were isolated to draw any conclusions, but studies on relatives of index cases in the Salt Lake City area suggest that mucoid strain M18 may be implicated. ${ }^{1}$ Maybe these mucoid strains are becoming more "rheumatogenic."

Although the incidence of acute rheumatic fever was falling before the era of antibiotics, vigorous treatment of streptococcal infections undoubtedly helped to hasten the decline. There is some evidence from the outbreaks that doctors have "gone soft" on the streptococcus and are often not making the diagnosis with throat swabs. And it is now unusual to give intramuscular penicillin followed by 10 days' oral treatment. Whether it is because of poor patient compliance or doctors' indifference the implication is that vigilance is lacking in diagnosing and treating streptococcal pharyngitis and tonsillitis.

A theory has also developed that some people have a genetic susceptibility to acute rheumatic fever. Patarroyo et al showed that a specific antiserum cross reacts with the serum of 60 to $70 \%$ of patients with rheumatic heart disease compared with $16 \%$ of specimens from the general population $^{6}$; and the determinant for this reaction is a B cell alloantigen. It is unlikely that a generation of genetically predisposed Americans are suddenly entering the age group affected by acute rheumatic fever, but explanations for the waxing of disease are often multifactorial.

The message for doctors in Britain and Europe is to treat streptococcal infections energetically and to collect background data so that they can detect any resurgence of acute rheumatic fever. Until new systems have been fully implemented, the only sources of morbidity information for acute rheumatic fever in England and Wales are the Hospital Activity Analysis or the Hospital Inpatient Enquiry. The inquiry is based on a $10 \%$ sampling of hospital discharges and deaths, and in 1963 the incidence of rheumatic fever in Britain was about 5 cases for every 100000 of the population.? Evidence from the enquiry suggested that there has been a tenfold reduction in acute rheumatic fever over the past 20 years (N D Noah, Communicable Diseases Surveillance Centre, personal communication). All data rely on the accuracy of diagnosis, and the British paediatric surveillance unit (through the British Paediatric Association) is looking at this problem. In January 1988 all paediatricians in the British Isles were asked to report any case of acute rheumatic fever confirmed by using the revised Jones criteria ${ }^{8}$ This requires two major or one major and two minor criteria plus evidence of streptococcal infection by throat swab or streptococcal antibodies. The incidence of cardititis may be higher in future because doctors will be able to use ultrasonography to study flow across the mitral valve. No doubt further requests for reporting of cases of acute rheumatic fever will be necessary, and we must support all efforts to prepare for an unwelcome return of this fascinating condition.

J G BISSENDEN

Consultant Paediatrician,

Dudley Road Hospital,

Birmingham B18 7QH

Veasy LG, Wiedmeier SE, Orsmond GS, et al. Resurgence of acute rheumatic fever in the intermountain area of the United States. N Engl f Med 1987;316:421-7.

Congeni B, Rizzo C, Conjeni J, Sreenivasan VV. An outbreak of acute rheumatic fever in northeast Ohio. F Pediatr 1987;111:176-9.

3 Hosier DM, Craenen JM, Teske DW, Wheeler JJ. Resurgence of acute rheumatic fever Am f Dis Child 1987;141:730-3.

4 Giardina AC. Resurgence of acute rheumatic fever. N Engl F Med 1987;317:507-8.

5 Chun LT, Reddy V, Yamamoto LG. Rheumatic fever in children and adolescents in Hawail. Pediatrics 1987;79:549-52.

6 Patarroyo ME, Winchester RJ, Vejerano A, et al. Association of B-cell alloantigen with susceptibility to rheumatic fever. Nature 1979;278:173-4.

Sanyal SK. Acute rheumatic fever and its sequelae during childhood: historical perspective and a global overview. Indian Pediatr 1987;4:275-94.

8 Ad Hoc Committee to revise the Jones Criteria (modified). Council on Rheumatic Fever and Congenital Heart Disease of the American Heart Association. Jones' Criteria (revised) for the guidance in the diagnosis of rheumatic fever. Circulation 1984;69:204-8A.

\title{
Tackling the bad driver
}

"The prime purpose of road traffic law" concludes the recently published Road Traffic Law Review "is to make roads safer." Although the most recently published casualty figures are encouraging, serious motor vehicle accidents will continue for many years to be a prime cause of permanent incapacity and death. Now that environmental measures to reduce the damage done by accidents are nearly exhausted, the need to control unsafe behaviour on the roads has become imperative. Although the government's report Road Safety: "The Next Steps," published last year, ${ }^{2}$ recognised this, its defeatist approach was a profound disappointment and underlined the doubts about the ability of the Department of Transport to get to grips with bad driving. ${ }^{3}$

The team that undertook the review has understood clearly this complex subject. Unfortunately the dead hand of the government may be detected in the exclusion from the terms of reference of both speed limits and blood alcohol concentration - two of the most important determinants of road accident trauma. Fortunately this has not prevented the group from referring extensively to both speed and alcohol in a 350 page report containing 137 unanimous recommendations.

Over two and a half million prosecutions are brought each year for offences related to motor vehicles, and they occupy between one half and three quarters of the time of magistrates courts. What public health authorities want to know is to 
what extent does all this activity reduce mortality and morbidity from road accidents? The review recognises that the existing law, particularly that dealing with bad driving and drinking driving, is defective, and it accepts that drivers do not understand the law and are not persuaded of its relevance to road safety.

The abolition of the offence of dangerous driving in 1977 left us with two bad driving offences-reckless driving and careless driving. Since then both the Criminal Law Revision Committee and the Law Commission have strongly criticised the retention of the term "reckless" in road traffic law ${ }^{45}$; furthermore, convictions are difficult to obtain as the courts insist on proof of a subjective state of mind in the driver. The group's answer to this is to recommend that the existing offences should be replaced by two new offences-very bad driving and bad driving. The definition suggested for the more serious offence would catch some drivers whose driving was very bad but who escape the conviction of reckless driving-in particular those seriously affected by alcohol. The less serious of the two offences would also be redefined to take account of the extended scope of the other offence so that the total effect would be to shift the boundary between the two existing offences downwards.

It is the consequences of bad driving that give rise to the most controversy. The offence of causing death by reckless or dangerous driving was introduced in 1956 because juries were reluctant to convict drivers of manslaughter. The offence was limited to reckless driving in 1977 because it was thought that conduct which did not include the moral culpability of recklessness did not merit conviction of such a serious offence. Some have since argued that it should be done away with altogether. Soundings taken by the review group left them in no doubt, however, that there was considerable public resentment about bad drivers responsible for causing death, particularly when they had been drinking. The group eventually decided to retain the causing death offence in the context of its new very bad driving offence, although not for the less serious offence. The group made one important exception: when the driver who had caused death had a blood alcohol concentration above the limit and his driving, while not bad enough to qualify within the more serious offence, showed lack of attention to the safety of other road users, he would be guilty of a new offence carrying the same penalties as those for the very bad driving offence-that is, imprisonment for up to five years, an unlimited fine, and obligatory disqualification from driving. Failure to take the breath test under the same circumstances would attract the same penalties.

Laws, however well formulated, cannot be effective unless they are easily and properly enforced. It takes on average nearly three months to bring a drinking driver to court, and $22 \%$ of cases take more than four months to complete, during which period the driver is free to continue driving. The offence is an absolute one, proof depending on an evidentiary breath test taking five minutes to administer. The delays and the police time wasted on the unnecessary procedures which parliament and the courts have insisted on are deplored by the review group, which has suggested that sometimes suspects should be stopped from driving until a full court hearing takes place. Police are urged to make better use of their time by testing drivers shortly after leaving public houses and hotels, something the BMA has repeatedly called for. The time wasted in the procedures the police have to follow in order to prosecute for speeding is also criticised, and the use of photography and video cameras is strongly recommended for both this and other offences such as failing to observe traffic lights.

Though rejecting the proposal that it should be made an offence to sell alcohol to intoxicated drivers, the review group urged licensing justices to take into consideration evidence that licensees have sold alcohol to motorists who go on to commit drinking offences. The so called St Christopher policies, which enable drivers to insure against the consequences of a drinking-driving conviction, are strongly criticised. It is a public scandal that such policies can be advertised.

There is a high rate of recidivism for road traffic offences, particularly for drinking driving. The review team were impressed with programmes in other countries for retraining, and it is recommended that a full trial should take place in Britain to ascertain how much the attitudes of offenders can be influenced. One in four deaths on the roads are caused by drinking drivers, and each death costs on average $£ 300000$. A trial costing $£ 1.25 \mathrm{~m}$ would equate with the cost of four road deaths, 100 prison sentences of a year's duration, or a small two level dual carriageway junction. Perhaps someone in government will see the point.

This report reflects the changing public attitude towards the responsibilities of drivers for the safety of other road users. The feeling that dangerous drivers need to be given a sporting chance by the police and that it is somehow unfair to use technology to detect them is rejected. The report concludes: "The detection and prosecution of the drink driver and of other bad drivers is no game. No sporting chance should be given." There are clear signs here that the importance to public health of road accident trauma and the extent to which this is caused by unsafe driver behaviour is at last being recognised.

JOHN HAVARD

Secretary, BMA

\footnotetext{
1 Department of Transport. Road traffic law review report. London: HMSO, 1988. 2 Department of Transport. Road safety: “the next steps." London: DOT, 1987.

3 Havard J. Twelve dead and a complacent report. Br Med f 1987;295:686.

4 Criminal Law Revision Committee. 14th Report. Offences against the person. London: HMSO, 1980: para 146. (Cmnd 7844.)

5 Law Commission. Draft criminal code. London: HMSO, 1985: para 8·24. (Report No 143.)
} 